\title{
Carbohydrate-induced Hypertriglyceridaemia in a Child ${ }^{\star}$
}

\author{
M. M. SEGALL, AUDREY S. FOSBROOKE, JUNE K. LLOYD, and O. H. WOLFF \\ From the Department of Child Health, Institute of Child Health, University of London
}

\begin{abstract}
Segall, M. M., Fosbrooke, Audrey S., Lloyd, June K., and Wolff, O. H. (1970). Archives of Disease in Childhood, 45, 73. Carbohydrate-induced hypertriglyceridaemia in a child. Carbohydrate-induced hypertriglyceridaemia is described in a 12-year-old boy, whose father died of premature coronary heart disease. Serum triglyceride and pre- $\beta$-lipoprotein concentrations were high on a self-selected diet and were reduced to normal by a low carbohydrate diet. It proved difficult to maintain triglyceride levels by diet at home, but the addition of clofibrate improved the control.

Clearing of lipid from the serum after an oral fat load was delayed when the fasting serum triglyceride was high, but became normal after the serum triglyceride had been reduced by diet. An oral glucose load showed impairment of glucose tolerance. Insulin resistance was suggested by a small decrease in plasma glucose, with a normal increase in serum insulin, after intravenous tolbutamide. Serum triglyceride and pre- $\beta$-lipoprotein concentrations increased after oral glucose. Observations in two other children with diabetic glucose tolerance curves suggested that the increase in serum triglyceride after oral glucose was related to the insulin response rather than to the degree of hyperglycaemia.
\end{abstract}

The term carbohydrate-induced hypertriglyceridaemia was introduced by Ahrens et al. (1961) to distinguish a type of hypertriglyceridaemia which responds to reduction in dietary carbohydrate; the triglyceride is endogenously synthesized and carried in the serum in pre- $\beta$-lipoprotein. This lipoprotein abnormality, which corresponds to Type IV hyperlipoproteinaemia in the classification of Fredrickson, Levy, and Lees (1967), may be secondary to other diseases such as diabetes mellitus or glycogen storage disease, but has also been reported as a 'primary' abnormality in adults. However, the 'primary' abnormality has not yet been described in childhood, the youngest affected subjects in the family studies of Fredrickson et al. (1967) being over 20 years of age. We report our investigations and treatment of a 12-year-old boy with the disorder, and describe an abnormal serum triglyceride response to an oral glucose load in this patient and also in a child with latent diabetes mellitus.

Received 3 June 1969.

*A preliminary report of part of this work has been presented to the British Paediatric Association (Segall. 1967).

\section{Subjects and Methods}

The patient (Case 1) was a prepubertal 12-year-old boy. Two years previously his father had died at the age of 34 years from a myocardial infarction and from that time the boy had developed a severe anxiety state. Physical examination showed no abnormality (weight 75th centile, height between 50th and 75th centiles), and his symptoms settled during his hospital admission and have not recurred. The father's serum cholesterol was reported as $265-300 \mathrm{mg}$. $100 \mathrm{ml}$., but his serum triglyceride and lipoprotein pattern are unknown. In the mother and a 10-year-old sister serum total lipid and cholesterol were determined 5 hours after a light breakfast, and found to be normal. The lipoprotein pattern was normal in the mother, though in the sister a faint pre- $\beta$-lipoprotein band was present.

Dietary studies were carried out, and the composition of the diets is given in Fig. 1. During period (A) he was hungry and therefore the calorie intake was increased and thereafter kept constant. During the periods of high carbohydrate feeding (A), (B), and (D), $75 \%$ of the carbohydrate was sucrose; during period (E) no sucrose was given and $75 \%$ of the carbohydrate was glucose; the remaining carbohydrate was starch and lactose. Serum lipids after an oral fat load $(2 \cdot 2 \mathrm{~g} . / \mathrm{kg}$. body weight in a mixed meal after an overnight fast), plasma post-heparin lipolytic activity, and the response to intravenous tolbutamide $(1 \mathrm{~g}$. as the 


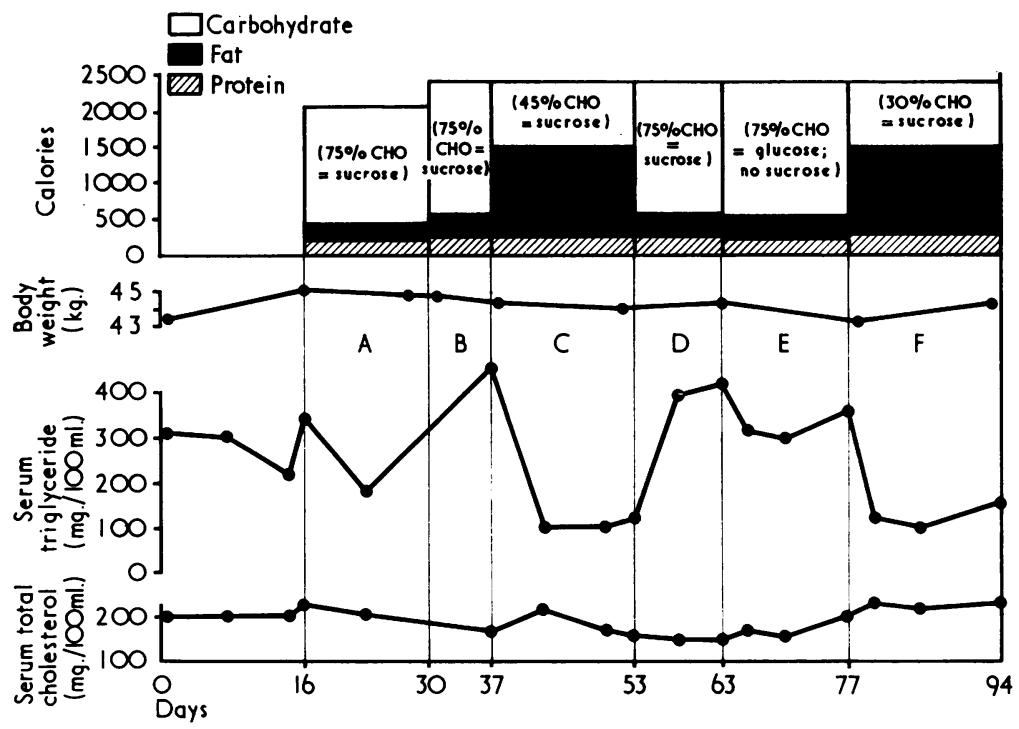

FIG. 1.-Effect of different diets on the serum triglyceride and cholesterol concentrations.

sodium salt in a $5 \% \mathrm{w} / \mathrm{v}$ solution in water given over 2 minutes) were also determined. Oral glucose loads were given to Case 1 and to two other children: a 9-yearold, mildly obese girl (Case 2; weight between 50 th and 75 th centiles, height 3 rd centile), who two years earlier had an episode of hyperglycaemia and hyperlipidaemia during an acute illness, and a 12-year-old boy (Case 3) with pancreatic hypoplasia. Glucose $(1.75 \mathrm{~g} . / \mathrm{kg}$. body weight, up to a maximum of $50 \mathrm{~g}$.) was given in a $25 \% \mathrm{w} / \mathrm{v}$ solution in water after an overnight fast, and changes in plasma glucose and nonesterified fatty acids (NEFA), and serum insulin, triglyceride, and lipoprotein pattern were observed.

Venous blood was used for all estimations and was taken after an overnight fast, except during the period of out-patient follow-up when it was taken about 4 hours after a standardized breakfast. Heparinized blood for plasma glucose and NEFA was cooled in ice and the plasma separated within half an hour.

Serum triglyceride was estimated in Case 1 by infrared absorptiometry (Freeman, 1964), with the exception of the first oral glucose load when it was estimated colorimetrically (Blankenhorn, Rouser, and Weimer, 1961); in Cases 2 and 3 serum triglyceride was estimated by quantitative gas-liquid chromatography (Fosbrooke and Tamir, 1968). Serum total cholesterol was estimated by a Liebermann-Burchard (Brown, 1961) or an Autoanalyser method (Technicon method N-24a); serum phospholipid (lipid phosphorus $\times 25$ ) by a modification of the method of Bartlett (1959); serum total lipid by a turbidimetric method (De la Huerga, Yesinick, and Popper, 1953); plasma post-heparin lipolytic activity by the method of Fredrickson, Ono, and Davis (1963); plasma glucose by a glucose oxidase method (Boehringe Corporation, 1968); plasma NEFA by the titration method of Dole and Meinertz (1960), and serum insulin by a modification (Grant, 1967) of the immunoassay procedure of Morgan and Lazarot (1963). Serum lipoproteins were separated by paper electrophoresis (Salt and Wolff, 1957).

\section{Results}

On the self-selected diet Case 1's serum woss slightly turbid, the triglyceride concentration wis $307 \mathrm{mg} . / 100 \mathrm{ml}$. (normal range $56-121 \mathrm{mg} . / 100 \mathrm{mF}$ obtained in 6 healthy children and 8 young adults) and a marked pre- $\beta$-lipoprotein band was present on paper electrophoresis (Fig. 2); the serum chole terol and phospholipid (197 mg./100 ml. and 208 mg./100 ml., respectively) were normal. The effect of different diets on the fasting serum trigly: ceride and cholesterol is shown in Fig. 1. When the carbohydrate was restricted to $38 \%$ of totol calories (periods (C) and (F)), the serum triglycerice decreased to normal When the carbohydrate wis increased to $78 \%$ of total calories in periods (B) (D), and (E) the serum triglyceride was increas only slightly above the level on his self-selected diet During period (A) when the calorie intake was insufficient the serum triglyceride decreased despiff the high proportion of carbohydrate. Whet glucose was substituted for sucrose in period (하) the hypertriglyceridaemia persisted. A marked pre- $\beta$-lipoprotein band was present during the periods of high carbohydrate feeding and dis appeared during carbohydrate restriction (Fig. 2y 


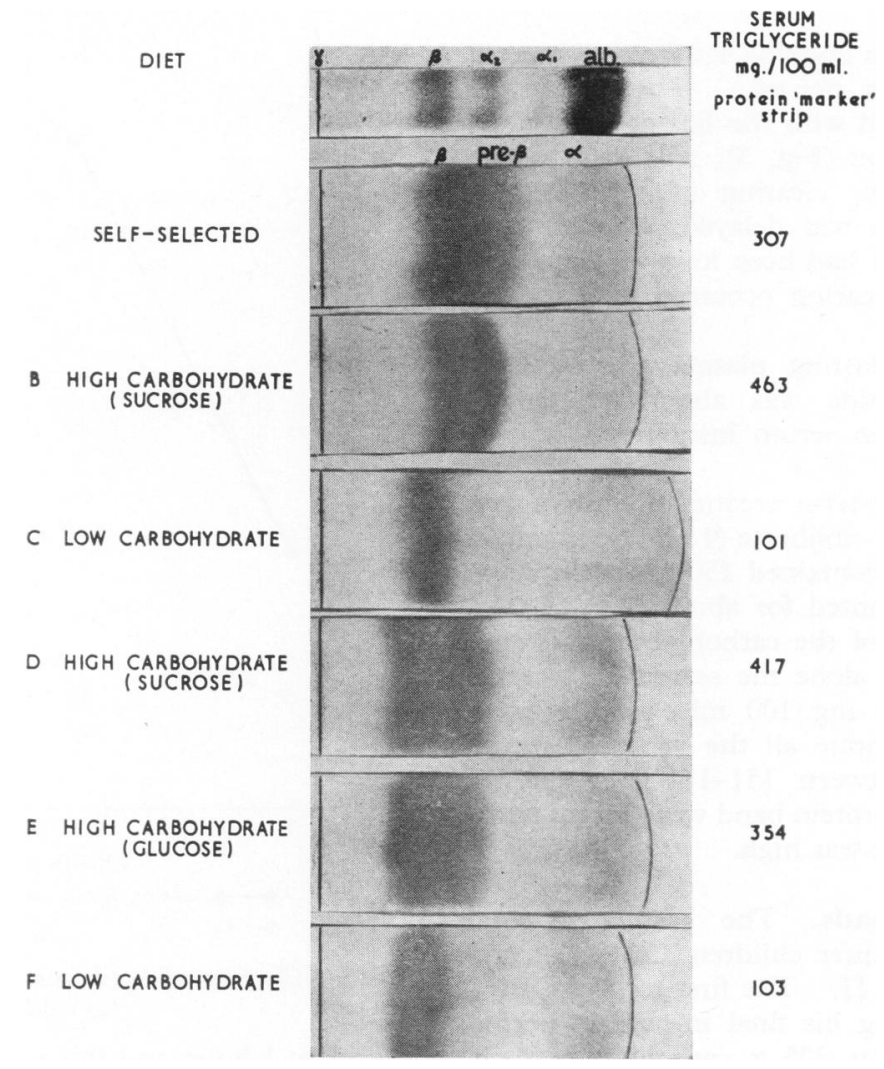

Fig. 2.-Effect of different diets on the serum lipoproteins (separated by paper electrophoresis). The letters B-F refer to the dietary periods shown in Fig. 1.

TABLE I

Intravenous Tolbutamide Test

\begin{tabular}{|c|c|c|c|c|c|c|c|}
\hline \multirow{2}{*}{$\begin{array}{l}\text { Minutes After } \\
\text { Tolbutamide }\end{array}$} & \multirow{2}{*}{$\begin{array}{l}\text { Plasma Glucose } \\
\quad(\mathrm{mg} . / 100 \mathrm{ml} .)\end{array}$} & \multicolumn{2}{|c|}{$\begin{array}{l}\text { Plasma Glucose } \\
\text { (\% basal concentration) }\end{array}$} & \multicolumn{2}{|c|}{$\begin{array}{c}\text { Serum Insulin } \\
\text { (uunits/ml.) }\end{array}$} & \multicolumn{2}{|c|}{$\begin{array}{l}\text { Plasma NEFA } \\
\quad(\mathrm{mEq} / \mathrm{l} .)\end{array}$} \\
\hline & & Case 1 & $\begin{array}{c}\text { Normal }{ }^{\star} \\
\text { (mean and range) }\end{array}$ & Case 1 & $\begin{array}{c}\text { Normal* } \\
\text { (mean and range) }\end{array}$ & Case 1 & $\begin{array}{c}\text { Normal }{ }^{\star} \\
\text { (mean and range) }\end{array}$ \\
\hline $\begin{array}{c}0 \\
(\text { geting }\end{array}$ & 103 & 100 & 100 & 6 & $\begin{array}{c}7 \\
(3-13)\end{array}$ & $1 \cdot 13$ & $1 \cdot 12$ \\
\hline 20 & 90 & 87 & $\begin{array}{c}68 \\
(63-76)\end{array}$ & 31 & $\begin{array}{c}43 \\
(16-85)\end{array}$ & 0.49 & $\begin{array}{c}0.80 \\
(0.60-1.02)\end{array}$ \\
\hline 30 & 72 & 70 & $\begin{array}{c}50 \\
(46-56)\end{array}$ & 14 & $\begin{array}{c}19 \\
(4-34)\end{array}$ & 0.40 & $\begin{array}{c}0.69 \\
(0.55-0.89)\end{array}$ \\
\hline 60 & 72 & 70 & $\begin{array}{c}72 \\
(64-80)\end{array}$ & 10 & $\begin{array}{c}10 \\
(2-15)\end{array}$ & $1 \cdot 30$ & $\begin{array}{c}1.07 \\
(0.66-1.57)\end{array}$ \\
\hline 90 & 98 & 95 & $\begin{array}{c}84 \\
(82-86)\end{array}$ & 7 & $\begin{array}{c}17 \\
(9-25)\end{array}$ & $1 \cdot 21$ & $\begin{array}{c}1 \cdot 22 \\
(1 \cdot 13-1 \cdot 30)\end{array}$ \\
\hline
\end{tabular}

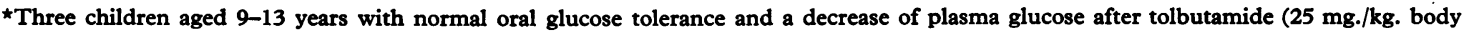
weight, to a maximum of $1 \mathrm{~g}$.) which was normal according to the criteria of Unger and Madison (1958). The insulin responses are similar to those found by Chiumello, del Guercio, and Bidone (1968). 
The serum cholesterol did not alter appreciably during the study.

Plasma post-heparin lipolytic activity was normal $(0.56 \mu \mathrm{Eq} \mathrm{NEFA} / \mathrm{min}$. per $\mathrm{ml}$.). The response to an oral fat load varied with the fasting serum triglyceride concentration (Fig. 3); when the serum triglyceride was high, clearing of the ingested lipid from the serum was delayed, whereas after the serum triglyceride had been lowered by carbohydrate restriction clearing occurred at a normal rate.

The decrease in fasting plasma glucose after intravenous tolbutamide was abnormally small, though the increase in serum insulin was normal (Table I).

The effect of long-term treatment with a low carbohydrate diet and clofibrate ( $1 \mathrm{~g}$./day) is shown in Fig. 4. The diet contained $150 \mathrm{~g}$. carbohydrate per day, which accounted for about $25 \%$ of total calories; about $20 \%$ of the carbohydrate was sucrose. With the diet alone the serum triglyceride varied from 139-385 mg./100 ml., whereas with the addition of clofibrate all the values observed except one were between 151-173 mg./100 ml. A marked pre- $\beta$-lipoprotein band was present when the serum triglyceride was high.

Oral glucose loads. The results of oral glucose loads on the three children (Cases 1,2, and 3) are given in Table II. The first test on Case 1 was performed during his final in-patient period when he was receiving $225 \mathrm{~g}$. carbohydrate daily ( $38 \%$ of calories). Glucose tolerance was impaired, the plasma glucose at 2 hours being $142 \mathrm{mg}$. $/ 100 \mathrm{ml}$. The increase in serum insulin and decrease in plasma NEFA were normal. The serum triglyceride increased from $119 \mathrm{mg} . / 100 \mathrm{ml}$. to $156 \mathrm{mg}$./

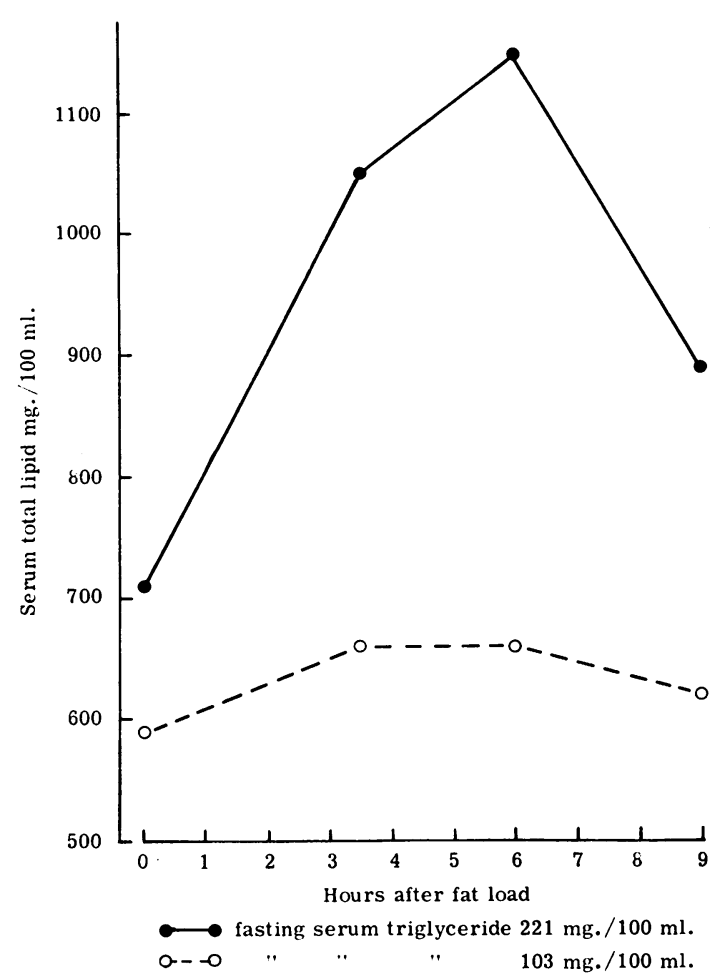

FIG. 3.-Clearing of lipid from the serum after an oral fat load.

$100 \mathrm{ml}$. at 1 hour, and this was accompanied by the appearance of pre- $\beta$-lipoprotein (Fig. 5); this response is abnormal. After 8 months of treatment with the low carbohydrate diet a second glucose load showed that there was no deterioration in glucose tolerance and that the serum triglyceride

Oral Glucose Loagt.

\begin{tabular}{|c|c|c|c|c|c|c|c|c|}
\hline \multirow{3}{*}{$\begin{array}{l}\text { Minutes After } \\
\text { Glucose }\end{array}$} & \multicolumn{7}{|c|}{ Case 1} & 3 \\
\hline & \multicolumn{4}{|c|}{$\begin{array}{l}\text { During Period }(F) \text { of Moderate } \\
\text { Carbohydrate Intake ( } 225 \mathrm{~g} . / \text { day) }\end{array}$} & \multicolumn{3}{|c|}{$\begin{array}{l}\text { After } 8 \text { Months on Low } \\
\text { Carbohydrate Intake ( } 150 \mathrm{~g} \text { /day) }\end{array}$} & $\stackrel{0}{2}$ \\
\hline & $\begin{array}{l}\text { Plasma Glucose } \\
\text { (mg./100 ml.) }\end{array}$ & $\begin{array}{l}\text { Plasma NEFA } \\
(\mathrm{mEq} / 1 .)\end{array}$ & $\begin{array}{l}\text { Serum Insulin } \\
\text { ( } \mu \text { units/ml.) }\end{array}$ & $\begin{array}{c}\text { Serum } \\
\text { Triglyceride } \\
\text { (mg./100 ml.) }\end{array}$ & $\begin{array}{l}\text { Plasma Glucose } \\
\text { (mg./100 ml.) }\end{array}$ & $\begin{array}{l}\text { Plasma NEFA } \\
\quad(\mathrm{mEq} / 1 .)\end{array}$ & $\begin{array}{c}\text { Serum } \\
\text { Triglyceride } \\
\text { (mg./100 ml.) }\end{array}$ & \\
\hline $\begin{array}{c}0 \\
\text { (fasting) } \\
30 \\
60 \\
90 \\
120 \\
150\end{array}$ & $\begin{array}{r}92 \\
\\
175 \\
193 \\
153 \\
142 \\
78\end{array}$ & $\begin{array}{l}1 \cdot 86 \\
0 \cdot 79 \\
0 \cdot 36 \\
0 \cdot 34 \\
0 \cdot 25 \\
0 \cdot 26\end{array}$ & $\begin{array}{r}4 \\
60 \\
81 \\
84 \\
58 \\
15\end{array}$ & $\begin{array}{l}119 \\
119 \\
156 \\
117 \\
117 \\
116\end{array}$ & \begin{tabular}{r|}
103 \\
\\
161 \\
199 \\
149 \\
122 \\
75
\end{tabular} & $\begin{array}{l}1 \cdot 44 \\
0.44 \\
0 \cdot 23 \\
0 \cdot 12 \\
0 \cdot 19 \\
0.74\end{array}$ & $\begin{array}{l}99 \\
91 \\
96 \\
91 \\
92 \\
95\end{array}$ & 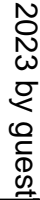 \\
\hline
\end{tabular}




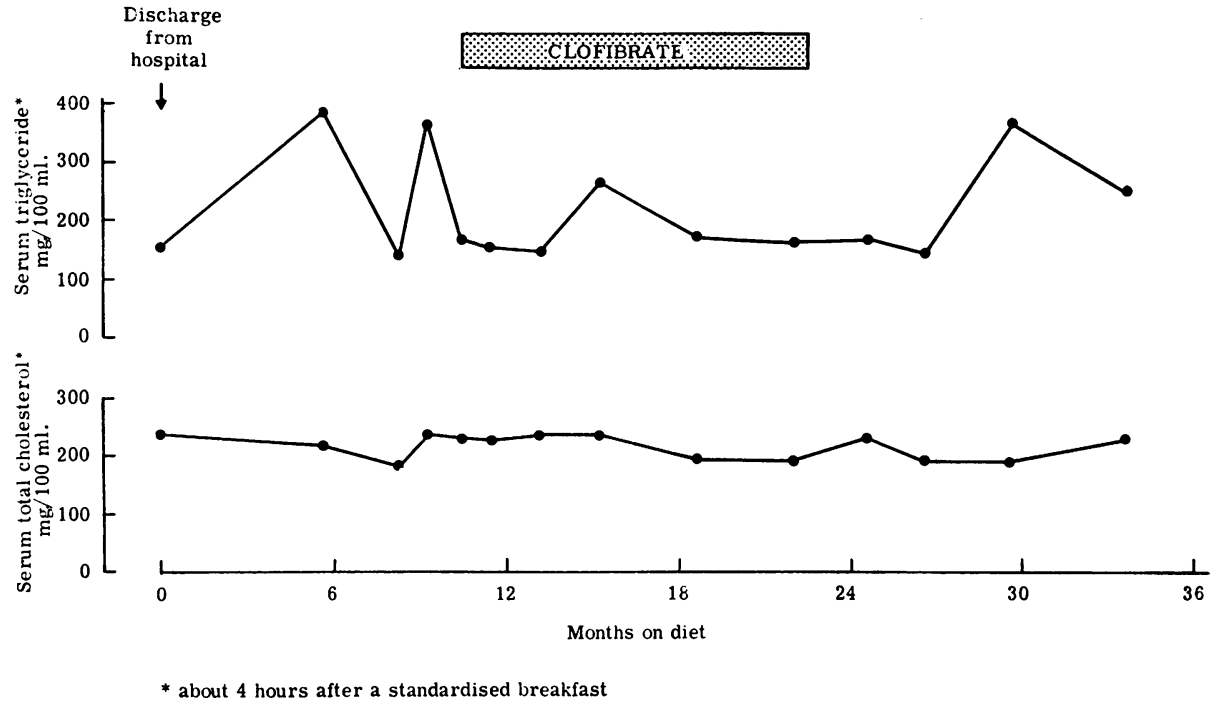

FIG. 4.-Effect of treatment at home with low-carbohydrate diet and clofibrate.

no longer increased after glucose; serum insulin was not estimated.

Case 2, the child who had latent diabetes mellitus and mild obesity, showed a diabetic glucose tolerance curve, a high serum insulin response, and a marked increase in serum triglyceride after oral glucose; by contrast, Case 3, the child with pancreatic hypoplasia who also had a diabetic tolerance curve, showed a low serum insulin response and a decrease in serum triglyceride after glucose.

\section{Discussion}

The lipoprotein abnormality in Case 1 corresponds to Type IV hyperlipoproteinaemia described by Fredrickson et al. (1967) in adults, and its correction by low carbohydrate feeding and exacerbation by high carbohydrate feeding fulfil the criteria for carbohydrate-induced hypertriglyceridaemia. Fredrickson et al. (1967) have reported the familial occurrence of this type of hyperlipoproteinaemia. The child's father, who died at the age of 34 years from a myocardial infarction, had a moderately increased serum cholesterol concentration, and though we do not know his serum triglyceride and lipoprotein pattern, this degree of hypercholesterolaemia is consistent with an increase in pre- $\beta$ -

\begin{tabular}{|c|c|c|c|c|c|c|c|}
\hline \multicolumn{4}{|c|}{ Case $2^{\star}$} & \multicolumn{4}{|c|}{ Case 3t } \\
\hline $\begin{array}{l}\text { Plasma Glucose } \\
\text { (mg./100 ml.) }\end{array}$ & $\begin{array}{c}\text { Plasma NEFA } \\
(\mathbf{m E q} / \mathbf{l} .)\end{array}$ & $\begin{array}{l}\text { Serum Insulin } \\
\text { ( } \mu \text { units/ml.) }\end{array}$ & $\begin{array}{l}\text { Serum Tri- } \\
\text { glyceride } \\
\text { (mg.',100 ml.) }\end{array}$ & $\begin{array}{l}\text { Plasma Glucose } \\
\text { (mg./100 ml.) }\end{array}$ & $\begin{array}{l}\text { Plasma NEFA } \\
\quad(\mathrm{mEq} / \mathrm{l} .)\end{array}$ & $\begin{array}{l}\text { Serum Insulin } \\
(\mu \text { units } / \mathrm{ml} .)\end{array}$ & $\begin{array}{l}\text { Serum Tri- } \\
\text { glyceride } \\
\text { (mg./100 ml.) }\end{array}$ \\
\hline 77 & $1 \cdot 00$ & 3 & 107 & 117 & $1 \cdot 11$ & 8 & 62 \\
\hline $\begin{array}{r}206 \\
229 \\
201 \\
120 \\
91\end{array}$ & $\begin{array}{l}0.88 \\
0.48 \\
0 \cdot 35 \\
0 \cdot 18 \\
0.17\end{array}$ & $\begin{array}{c}105 \\
175 \\
95 \\
80 \\
38\end{array}$ & $\begin{array}{l}114 \\
123 \\
133 \\
181 \\
183\end{array}$ & $\begin{array}{l}191 \\
260 \\
255 \\
206 \\
133\end{array}$ & $\begin{array}{l}0.79 \\
0.41 \\
0.33 \\
0.31 \\
0.24\end{array}$ & $\begin{array}{l}15 \\
23 \\
36 \\
39 \\
21\end{array}$ & $\begin{array}{l}51 \\
57 \\
58 \\
46 \\
39\end{array}$ \\
\hline
\end{tabular}


lipoprotein. It is also possible that the faint pre- $\beta$-lipoprotein band found in the sister of Case 1 indicates the same abnormality.

Despite the patient's good response to carbohydrate restriction in hospital, his long-term management at home with diet alone was unsatisfactory. Clofibrate (ethyl- $a-p-c h l o r o p h e n o x y i s o-$ butyrate) is reported to lower the serum triglyceride in this type of hyperlipoproteinaemia (Oliver,

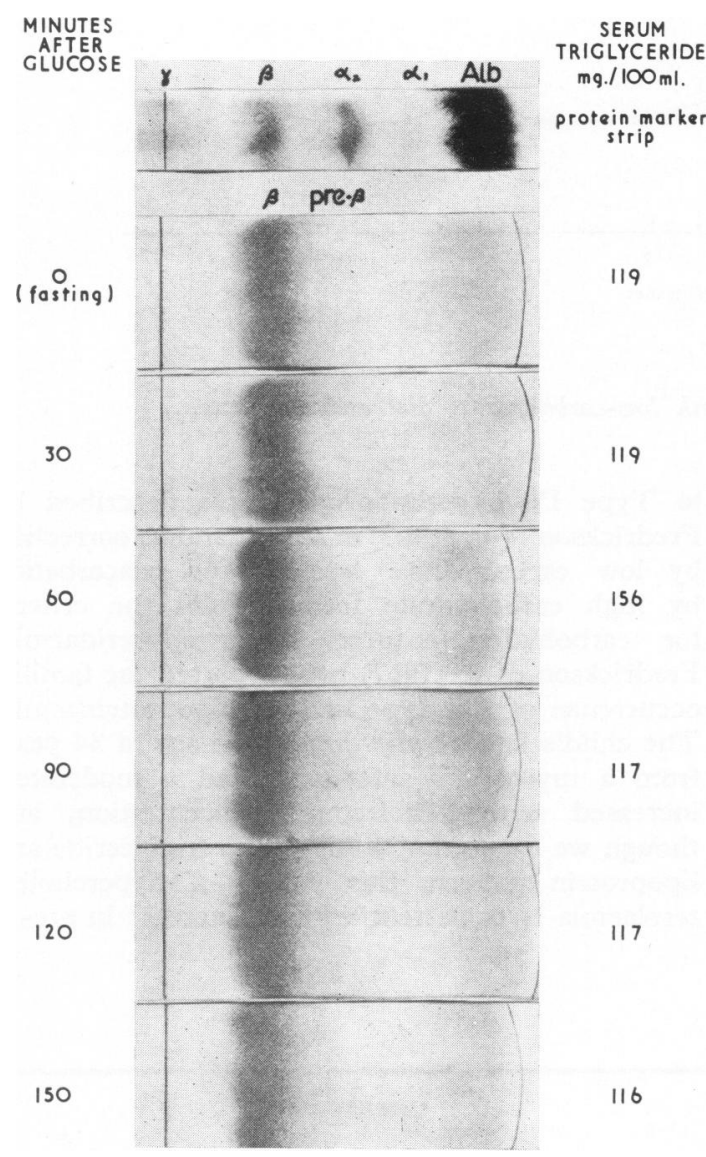

Fig. 5.-Appearance of pre- $\beta$-lipoprotein after an oral glucose load.

1967). We did not use this drug alone in our patient, but when it was combined with dietary treatment reasonable control of his serum triglyceride was achieved at home. The findings of delayed clearing of lipid from the serum after a fat meal when pre- $\beta$-lipoprotein triglyceride was high, and of normal clearing when the triglyceride had been reduced, are in keeping with the observa- tion of Nestel (1964) in adults that the rate of moval of chylomicron triglyceride is inversedy proportional to the fasting plasma triglyceride concentration. Reaven et al. (1965) have showh that the capacity for clearing pre- $\beta$-lipoprotem triglyceride becomes readily saturated. T⿳⺈⿵冂⿻丷木大 delayed clearing of chylomicron triglyceride when pre- $\beta$-lipoprotein triglyceride is raised sugge that the triglyceride in both lipoproteins is removed by the same clearing mechanism. The finding on our patient of normal plasma post-heparin lipeslytic activity indicates that lipoprotein lipase (the enzyme responsible for hydrolysis of lipoprotein triglyceride) is present, and that the clearigh defect is probably due to an excess of substrafe rather than to a lack of enzyme.

Carbohydrate-induced hypertriglyceridaemia results from increased hepatic synthesis of te glyceride, which is secreted into the serum in prets $\beta$-lipoprotein. Impaired glucose tolerance is commonly found in adults with the condition (Kañe et al., 1965; Fredrickson et al., 1967), and the increased hepatic synthesis of triglyceride probabigy results from hyperinsulinaemia (Reaven et $a \mathfrak{a}$, 1967) secondary to insulin resistance (Davids@in and Albrink, 1965). In Case 1, who had impaired oral glucose tolerance, some degree of ingufin resistance may be inferred, since after intrave ous tolbutamide only a small decrease in pkss. glucose occurred despite a normal rise in serựn insulin. A similar abnormality in the intraveno tolbutamide test has been found in adults with carb.hydrate-induced hypertriglyceridaemia (Knit and Ahrens, 1964).

In normal subjects a small decrease in serưn triglyceride occurs after an oral glucose loळd (Rubenstein et al., 1969); the increase found $\overline{\text { In }}$ Case 1 appears to be a new observation in carbohydrate-induced hypertriglyceridaemia. In ouir other patients, both of whom had diabetic glucsise tolerance curves, the serum triglyceride increased in Case 2 in association with her high insubn response, and decreased in Case 3 in association with his low insulin response. This differenfe in response suggests that the increase in serum triglyceride after oral glucose is related to the insuin response rather than to the degree of hyperglycaemia.

The diagnosis of carbohydrate-induced hyp@ triglyceridaemia is best made by showing a decrease in the fasting serum triglyceride on low-carbhydrate feeding. The finding of an increase gin serum triglyceride on high-carbohydrate feediĝg is not diagnostic of the condition because such ${ }^{+} a$ response is normal in both children (Seg교 
et al., 1970) and adults (Lees and Fredrickson, 1965). However, in subjects in whom fasting serum triglyceride concentrations are not clearly abnormal, the magnitude of the increase in triglyceride after high-carbohydrate feeding may prove useful in diagnosis, as may also the triglyceride response to an oral glucose load.

We would like to thank Dr. T. H. Hughes-Davies for referring Case 1, Dr. D. B. Grant and Mrs. D. Jackson for the serum insulin estimations, and the staff of the Dietetic Department, The Hospital for Sick Children, Great Ormond Street, for their help. M.M.S. was in receipt of a fellowship from the Wellcome Trust.

\section{REFERENCES}

Ahrens, E. H., Jr., Hirsch, J., Oette, K., Farquhar, J. W., and Stein, Y. (1961). Carbohydrate-induced and fat-induced lipemia. Transactions of the American Association of Physicians, 74, 134.

Bartlett, G. R. (1959). Phosphorus assay in column chromatography. Journal of Biological Chemistry, 234, 466.

Blankenhorn, D. H., Rouser, G., and Weimer, T. J. (1961). A method for the estimation of blood glycerides employing florisil. Fournal of Lipid Research, 2, 281.

Boehringe, C. F. Corporation (1968). Enzymatic Determination of 'True Glucose'. Mannheim.

Brown, W. D. (1961). A filtration procedure for determining serum cholesterol with digitonin. Australian fournal of Experimental Biology and Medical Science, 39, 223.

Chiumello, G., del Guercio, M. J., and Bidone, G. (1968). Effects of glucagon and tolbutamide on plasma insulin levels in children with ketoacidosis. Diabetes, 17, 133.

Davidson, P. C., and Albrink, M. J. (1965). Insulin resistance in hyperglyceridemia. Metabolism, 14, 1059.

De la Huerga, J., Yesinick, C., and Popper, H. (1953). Estimation of total serum lipids by a turbidimetric method. American fournal of Clinical Pathology, 23, 1163.

Dole, V. P., and Meinertz, H. (1960). Microdetermination of long-chain fatty acids in plasma and tissues. Fournal of Biological Chemistry, 235, 2595.

Fosbrooke, A. S., and Tamir, I. (1968). A modified method for the preparation of methyl esters of a mixture of medium-chain and long-chain fatty acids. Clinica Chimica Acta, 20, 517.

Fredrickson, D. S., Levy, R. I., and Lees, R. S. (1967). Fat transport in lipoproteins: an integrated approach to mechanisms and disorders. New England fournal of Medicine, 276, 34, 94, 148,215 and 273.
-, Ono, K., and Davis, L. L. (1963). Lipolytic activity of postheparin plasma in hyperglyceridemia. Fournal of Lipid Research 4, 24.

Freeman, N. K. (1964). Simultaneous determination of triglycerides and cholesterol esters in serum by infrared spectrophotometry. ibid., 5, 236.

Grant, D. B. (1967). Fasting serum insulin levels in childhood. Archives of Disease in Childhood, 42, 375.

Kane, J. P., Longcope, C., Pavlatos, F. C., and Grodsky, G. M. (1965). Studies of carbohydrate metabolism in idiopathic hypertriglyceridemia. Metabolism, 14, 471.

Knittle, J. L., and Ahrens, E. H., Jr. (1964). Carbohydrate metabolism in two forms of hyperglyceridemia. Fournal of Clinical Investigation, 43, 485.

Lees, R. S., and Fredrickson, D. S. (1965). Carbohydrate induction of hyperlipemia in normal man. (Abstr.) Clinical Research, 13, 327.

Morgan, C. R., and Lazarow, A. (1963). Immunoassay of insulin: two antibody system. Diabetes, 12, 115 .

Nestel, P. J. (1964). Relationship between plasma triglycerides and removal of chylomicrons. Fournal of Clinical Investigation, 43, 943.

Oliver, M. F. (1967). The present status of clofibrate (Atromid-S). Circulation, 36, 337.

Reaven, G. M., Hill, D. B., Gross, R. C., and Farquhar, J. W. (1965). Kinetics of triglyceride turnover of very low density lipoproteins of human plasma. Fournal of Clinical Investigation 44, 1826.

_, Lerner, R. L., Stern, M. P., and Farquhar, J. W. (1967). Role of insulin in endogenous hypertriglyceridemia. ibid., 46, 1756.

Rubenstein, A. H., Seftel, H. C., Miller, K., Bersohn, I., and Wright, A. D. (1969). Metabolic response to oral glucose in healthy South African White, Indian and African subjects. British Medical fournal., 1, 748.

Salt, H. B., and Wolf, O. H. (1957). The applications of serum lipoprotein electrophoresis in paediatric practice. Archives of Disease in Childhood, 32, 404.

Segall, M. M. (1967). Carbohydrate-induced hypertriglyceridaemia. (Abstr.) ibid., 42, 566.

—, Tamir, I., Fosbrooke, A. S., Lloyd, J. K., and Wolf, O. H. (1970). The effects of short-term high carbohydrate feeding on serum triglyceride of children with familial hypercholesterolaemia. Archives of Disease in Childhood, (in the press).

Technicon Instruments. Technicon method N-24a, Total cholesterol. Chertsey, Surrey.

Unger, R. H., and Madison, L. L. (1958). A new diagnostic procedure for mild diabetes mellitus. Diabetes, 7, 455.

Correspondence to Dr. June K. Lloyd, Institute of Child Health, 30 Guilford Street, London W.C.1. 